\title{
ARTICLE
}

\section{The Vital Center Reborn: Redefining Liberalism between $9 / 11$ and the Iraq War}

\author{
Joseph Stieb
}

(Received 9 February 2020; revised 8 August 2021; accepted 9 August 2021)

Following the 9/11 terrorist attacks, a set of liberal intellectuals promoted a vision of liberal renewal at home and abroad, hoping to create a new political and foreign policy paradigm. They sought to revive a form of early Cold War "Vital Center" liberalism by supporting democratization and human rights, designing a liberal version of patriotism, and supporting confrontations with illiberal autocracies and radical Islamists. They hoped to reverse decades of liberal decline in domestic politics, to distance themselves from the political left, and to critique President George Bush's response to 9/11, which they viewed as unilateralist, militaristic, and intellectually vapid. This revival of optimistic, universalist liberalism represents the peak of liberals' post-Cold War belief in the ability of U.S. power to spread presumably universal values. The failure of the Iraq War, which many of these thinkers supported, undermined this brief project and returned liberals to a more cautious, defensive mindset.

The period between the September 11, 2001, terrorist attacks in the United States and the 2003 U.S. invasion of Iraq was one of mourning, anger, and dread for Americans, but it also featured flux and opportunity. During this period, the response to 9/11 remained largely undetermined, as did the meaning of this event for Americans' identities and values. Thinkers of various ideological camps sensed an opening for sweeping new visions of the U.S. role in the world and its core values. The George W. Bush administration responded with a War on Terror that sought not only to defeat the direct perpetrators of the attacks, but also to compel state sponsors of terrorism to cease their behavior or face regime change. This conflict began with the U.S. invasion of Afghanistan in the fall of 2001, but the administration soon turned to Iraq as the centerpiece of the War on Terror, despite the lack of connections between Iraq and 9/11. By invading Iraq in March 2003, Bush hoped to eliminate a threat to national security and possibly spark democratic reforms in the Middle East that would undermine the appeal of religious extremism. ${ }^{1}$

In order to correct what they viewed as the flaws of Bush's response to terrorism, a distinct group of liberal thinkers after 9/11 developed their own ambitious vision for the budding War on Terror-and more broadly for the meaning of liberalism in domestic politics. Crucial actors in the designing of a distinct liberal response to $9 / 11$ included the editorial board of Dissent; the journalists George Packer, Peter Beinart, and Paul Berman; the activist Todd Gitlin; Salon founder David Talbot; the scholars Michael Ignatieff, Michael Kazin, and Samantha Power; and the ethicist Michael Walzer. Packer, Beinart, Ignatieff, and Berman openly identified as liberals and self-consciously sought to design a liberal War on Terror. Figures like Kazin, Gitlin, and Walzer identified as progressives or leftists, but they had become alienated from much of leftist thought. With the exception of the Iraq War, their outlook on the U.S. role in the world

Thanks to the Mershon Center for International Security Studies at the Ohio State University for support during the revision of this article. Thanks also to Joshua Tait, Robert Colby, Eric Burke, Jeffrey Stieb, and MAH's Barbara Keys.

${ }^{1}$ Douglas Little, Us Versus Them: The United States, Radical Islam, and the Rise of the Green Threat (Chapel Hill, NC, 2016), 145-55.

(C) The Author(s), 2021. Published by Cambridge University Press 
came to align closely with that of the self-identified liberals. Together they offered a liberal version of the War on Terror that challenged Bush's post-9/11 foreign policy and sought to correct what they viewed as the wayward path of liberal thought and politics in the preceding decades.

These thinkers envisioned a liberal War on Terror that would carve out space "between Cheney and Chomsky," as the writer Michael Tomasky put it, referring to the conservative Dick Cheney and the far-left thinker Noam Chomsky. This required fostering a vibrant, selfconfident liberalism that would defend human rights, democracy, and multilateral foreign policy. ${ }^{2}$ On one hand, they viewed the Bush administration as a bastion of militaristic neoconservatives who saw the United States as an unrestrained global hegemon. On the other hand, they saw much of the contemporary antiwar left as cynical, relativistic, rigidly devoted to the idea of the United States as an imperialist bully, and incapable of contributing realistic ideas to the national defense. These actors also believed that liberalism since the 1960s had declined from its mission of using government to ensure justice and equality into a cacophony of disparate identity and interest groups. They lamented the modern Democratic Party's near abandonment of liberalism, embodied by President Bill Clinton's triangulation strategy of adopting of conservative rhetoric and policies to co-opt conservative political momentum. Instead, they wanted to unite the campaign against terrorism with political reforms in the Middle East as well as bold efforts at social and economic justice at home, tackling issues like environmentalism and income inequality. This rejuvenated liberalism, moreover, would embrace patriotism by redefining it as self-critically holding one's country to its proclaimed principles, in contrast to the right's "love it or leave it" jingoism. After 9/11, they hoped that this project would challenge the reckless arrogance of the neoconservatives, counter the reflexive anti-Americanism of the left, and provide the wishy-washy moderates of the Democratic Party with a vision that could reverse the conservative ascendency in U.S. politics since the 1970s.

This vision of liberal renewal between $9 / 11$ and the Iraq War can be conceptualized as the New Vital Center, a reference to the early Cold War "Vital Center" liberalism of historian Arthur Schlesinger Jr., theologian Reinhold Niebuhr, and President Harry Truman. Many of the early twenty-first-century liberals in this story modeled their project on the Cold War Vital Center. ${ }^{3}$ They admired liberal Cold Warriors' commitment to containing the totalitarian menace of Soviet communism, their isolating of the left in the United States, and their devotion to progressive reform. The New Vital Center liberals imagined the early Cold War, the era of the so-called liberal consensus in U.S. politics, as the heyday of modern liberalism and a model for the present. They did not aim to be centrist or moderate, as they believed Clinton did, but sought to reinstall liberalism as the dominant paradigm of domestic politics and foreign policy, a position they believed it had occupied in the early Cold War.

Historians and other scholars who have examined post-9/11 liberalism's relationship to U.S. foreign policy have often portrayed pro-war liberals as "useful idiots" who parroted neoconservative rationales for global hegemony and regime change in Iraq, thereby helping drown out critical voices and facilitating a disastrous overextension of U.S. power. ${ }^{4}$ This argument ignores the New Vital Center liberals' strident critiques of Bush's foreign policy and their meaningfully

\footnotetext{
${ }^{2}$ Michael Tomasky, "Between Cheney and Chomsky: Making a Domestic Case for a New Liberal Foreign Policy," in The Fight is for Democracy: Winning the War of Ideas in America and the World, ed. George Packer (New York, 2003), 21-48.

${ }^{3}$ Peter Beinart, “A Fighting Faith,” The New Republic, Dec. 13, 2004, 17-29; George Packer, “America's Age of Empire," Mother Jones, Jan./Feb. 2003, 35, 38-9.

${ }^{4}$ Tony Judt, "Bush's Useful Idiots," London Review of Books, Sept. 16, 2006, https://www.lrb.co.uk/v28/n18/tonyjudt/bushs-useful-idiots (accessed Aug. 2, 2021). For similar criticisms, see Maria Ryan, "Bush's 'Useful Idiots': 9/ 11, the Liberal Hawks and the Cooption of the 'War on Terror," Journal of American Studies 45, no. 4 (Nov. 2011): 667-93, here 670; David Clark, "Iraq Has Wrecked Our Case for Humanitarian Wars," The Guardian, Aug. 12, 2003, https:/www.theguardian.com/politics/2003/aug/12/iraq.iraq1 (accessed Aug. 2, 2021); and Michael Bérubé, The Left at War (New York, 2016), 144.
} 
different arguments for the Iraq War. To date, the political theorists who have dominated this conversation have focused on whether some essential version of liberalism can be blamed or excused for the war. Many scholars have blamed liberal ideas for the hyper-optimism that contributed to the U.S. invasion: the Wilsonian dream of a universal democracy, the discounting of the enduring strength of nationalism and religion, and an intolerance for co-existence with nonliberal regimes. ${ }^{5}$ Liberal international relations theorists have responded that the Iraq War resulted from neoconservative or realist-minded pursuit of "hegemonic primacy" in the Middle East and that liberalism is inherently anti-imperialism. ${ }^{6}$

These theorists rely on decontextualized, essentialized conceptions of liberalism that fail to explain changes in liberal thought as well as debates within liberalism itself. They are less focused on assessing liberal ideas historically than on scoring points in contemporary policy debates over the U.S. global role. In contrast, this article takes a historical approach that treats liberalism as a set of principles with significant continuity over time that is also expansive and malleable enough to be pro-war or antiwar and pro-imperialist or anti-imperialist depending on the context, the thinker's purposes, and their interpretation of liberal precepts. In this approach, the historian explains changes over time and divisions within liberalism, or what historian Jennifer Pitts calls "the articulation of liberalism as a practice." 7

Using this approach, this study of the New Vital Center contends that modern U.S. liberalism has oscillated between "optimistic-universal" and "cautious-historical" modes. The New Vital Center liberals represented a striking, if brief, instance of the optimistic-universal vision in that they believed that liberal values not only should apply, but do apply, to all societies. ${ }^{8}$ Moreover, most of them held that U.S. power should be used to promote these values abroad. This particular articulation of liberalism reflected key contextual factors as well as the actors' priorities. These include the rising importance of human rights and humanitarian interventionism since the 1970s, the conviction that the end of the Cold War signified the global victory of liberal ideas, and the belief that the embrace of universal ethics and patriotism would counter conservative political dominance. These forces primed these thinkers to embrace moral universalism as the heart of their project and the essential meaning of liberalism itself. ${ }^{9}$ This interpretation motivated many of them to support the Iraq War because of a perceived moral responsibility to all oppressed people, the desire to spread democracy, and the narrative of an ongoing liberal struggle against totalitarianism.

However, the New Vital Center liberals overlooked that the liberalism of the Cold War Vital Center had been chastened by the collision with war, totalitarianism, and the underside of human nature. Figures such as Schlesinger and Niebuhr did support an active foreign policy and incremental domestic reform, but they dreaded mass politics and utopian ideologies, which they saw as possible roads to totalitarianism. They eschewed the optimism of many Progressives and New Deal liberals about the capacity of reason and enlightened government

\footnotetext{
${ }^{5}$ John Mearsheimer, The Great Delusion: Liberal Dreams and International Realities (New Haven, CT, 2018), 130-49. See also Michael C. Desch, “America's Liberal Illiberalism: The Ideological Origins of Overreaction in U.S. Foreign Policy," International Security 32, no. 3 (Winter 2007/2008): 7-43, here 14-5, 30-2; Eric A. Heinze, "The New Utopianism: Liberalism, American Foreign Policy, and the War in Iraq," Journal of International Political Theory 4, no. 1 (Apr. 2008): 105-25, here 116-25; Patrick Porter, "Iraq: A Liberal War After All: A Critique of Dan Deudney and John Ikenberry," International Politics 55, no. 2 (Mar. 2018): 33448, here 338-42; and Patrick J. Deneen, Why Liberalism Failed (New Haven, CT, 2018), 50.

${ }^{6}$ Daniel Deudney and G. John Ikenberry, "Realism, Liberalism, and the Iraq War," Survival 59, no. 4 (Aug.-Sept. 2017): 7-26, here 7-9, 17-22.

${ }^{7}$ Duncan Bell, "What Is Liberalism?” Political Theory 42, no. 6 (Dec. 2014): 682-715, here 690-1; Jennifer Pitts, A Turn to Empire: The Rise of Imperial Liberalism in Britain and France (Princeton, NJ, 2005), 4-5.

${ }^{8}$ This formulation of liberal thought is borrowed from Mearsheimer, The Great Delusion, 52.

${ }^{9}$ Mark Mazower, Governing the World: The History of an Idea, 1815 to the Present (New York, 2012), 379-80; Samuel Moyn, The Last Utopia: Human Rights in History (Cambridge, MA, 2010), 1-11.
} 
to cure social ills and direct economic affairs. ${ }^{10}$ They more often viewed liberalism as a particular inheritance of Western societies and a program of individualism, first and foremost. As Schlesinger declared in 1949: "The conception of a free society-a society committed to the protection of the liberties of conscience, expression, and political opposition-is the crowning glory of western history." 11 Followers of this "cautious-historical" mode of liberalism were more aware of the potential for utopian schemes to backfire, the limits of power in achieving moral ends, and the hubris that accompanies claims of universal morality. The philosopher Judith Shklar, herself a Jewish refugee from Nazi oppression in Latvia, aptly described this as the "liberalism of fear": a cautious ideology more concerned with resisting nightmarish forces like totalitarianism and genocide than offering a global, universal vision of reform. $^{12}$

The Iraq War eventually divided the New Vital Center over the recurring tension in U.S. liberalism over the degree to which liberals should embrace the use of military power for liberal ends. Prowar liberals reconciled themselves to the use of this power in Iraq, but Walzer, Gitlin, and others, while maintaining universalistic principles, challenged the idea that democracy could be installed through war and argued that invading Iraq was neither ethical, wise, nor necessary. They opposed the Iraq War in part for pragmatic, case-specific reasons, but on a deeper level they shared the Cold War Vital Center liberals' suspicion of utopian projects, which, as in the Iraq case, could create hell from heavenly dreams. Ultimately, the failure of the Iraq War discredited the New Vital Center vision and helped put liberal thought and Democratic party politics relating to the U.S. global role on a more cautious trajectory.

\section{Liberal Roads to a Post-9/11 Foreign Policy}

Liberalism has undergone many permutations, but historian Gary Gerstle identifies three consistent principles: "emancipation" of the individual from arbitrary powers or social restraints; "rationality," or the belief in reason as the primary means of understanding the world; and "progress," or the belief in the steady but constant improvement of human life and the greater inclusion of marginalized groups in the circle of rights and prosperity. ${ }^{13}$ Gerstle contends that the historical study of liberalism boils down to understanding "a series of efforts to reinterpret these principles in light of unexpected historical developments." 14

Mid- and late-twentieth century U.S. liberalism has been devoted to individual liberties, human rights, constitutional government, regulated capitalism, progress on issues like race and gender, and the belief that government can enhance the freedom and welfare of citizens. ${ }^{15}$ What scholars describe as modern liberal internationalism, or the application of liberal ideas in

\footnotetext{
${ }^{10}$ For more on this shift in postwar liberal thinking, see Alan Brinkley, The End of Reform: New Deal Liberalism in Recession and War (New York, 1995); David Ciepley, Liberalism in the Shadow of Totalitarianism (Cambridge, MA, 2006); Jennifer A. Delton, Rethinking the 1950s: How Anticommunism and the Cold War Made America Liberal (New York, 2013), 15-22; and Helena Rosenblatt, The Lost History of Liberalism: From Ancient Rome to the Twenty-First Century (Princeton, NJ, 2018), 269. For examples from the early postwar period, see Reinhold Niebuhr, The Children of Light and the Children of Darkness: A Vindication of Democracy and a Critique of its Traditional Defense, 2nd ed. (New York, 1960), 1-41; and Arthur M. Schlesinger, Jr., The Vital Center: The Politics of Freedom, 3rd ed. (New Brunswick, NJ, 1998), xvii-xix.

${ }^{11}$ Schlesinger, Vital Center, 8.

${ }^{12}$ Judith N. Shklar, "The Liberalism of Fear," in Liberalism and the Moral Life, ed. Nancy L. Rosenblum (Cambridge, MA, 1989), 21-38. See also Michael Freeden and Marc Stears, "Liberalism," in The Oxford Handbook of Political Ideologies, eds. Michael Freeden, Lyman Tower Sargent, and Marc Stears (Oxford, 2013), 329-47, here 335-7.

${ }^{13}$ Gary Gerstle, “The Protean Character of American Liberalism," American Historical Review 99, no. 4 (Oct. 1994): 1043-73, here 1046; Alan Ryan, The Making of Modern Liberalism (Princeton, NJ, 2012), $24-34$.

${ }^{14}$ Gerstle, "Protean Character," 1046; James T. Kloppenberg, The Virtues of Liberalism (New York, 1998), 9.

${ }^{15}$ Bruce Schulman, Lyndon B. Johnson and American Liberalism: A Brief Biography with Documents (New York, 2007), 13-5; Freeden and Stears, "Liberalism," 329-31; Kloppenberg, Virtues of Liberalism, 10.
} 
international politics, aims to tame destructive geopolitical competition with a system of rules-based multilateral institutions like the United Nations and the North Atlantic Treaty Organization, international law, and universal norms of human rights and democracy. ${ }^{16}$

The New Vital Center project must be placed in the context of U.S. liberalism since World War II. These thinkers believed that liberalism had declined since its heyday in the 1950s and 1960s, and their efforts at redefinition required reviving the confidence and patriotism of early postwar liberalism in order to arrest this perceived decline. Historians generally view the two decades after World War II as a liberal era in U.S. politics. Building on the New Deal, postwar liberals helped fashion government programs that regulated economic activity, maintained high levels of consumption, provided a social safety net, and boosted opportunities for the middle class. ${ }^{17}$ Liberals were also some of the toughest Cold Warriors. Truman launched a global campaign to contain communism, and liberals like Schlesinger staunchly backed this effort. The fact that President Dwight D. Eisenhower did not roll back New Deal programs suggested to many observers that a liberal consensus now dominated politics. ${ }^{18}$

New Vital Center liberals hoped to resuscitate early Cold War liberalism's commitment to antitotalitarianism, which had first become an organizing concept for liberals in the 1930s and 1940s. For thinkers such as Schlesinger, Niebuhr, and the philosopher Sidney Hook, Soviet communism and Nazi fascism were two sides of an unprecedented revolt against liberalism and democracy. ${ }^{19}$ The publication of influential books about totalitarianism added to the currency of the concept, including George Orwell's 1984 (1949) and Hannah Arendt's The Origins of Totalitarianism (1951). The idea of totalitarianism became part of the political vocabulary of liberals and conservatives, and President Truman, Secretary of State George Marshall, and other top officials used it in speeches. ${ }^{20}$

This mission had deep roots in liberal thought, especially the idea that a state's political system and official ideology determined its behavior. In this view, a variety of regimes existed, including democracies, autocracies, and oligarchies, but totalitarian regimes posed the greatest threat to human rights and world peace. They sought total control of life and thought within their borders, and they usually launched radical efforts to create utopias. ${ }^{21}$ Liberal thinkers argued that totalitarian regimes almost inevitably attacked or sought to destabilize other states because their leaders embraced absolutist ideologies and were not accountable to their people or other branches of government. Such regimes often started conflicts abroad to rationalize domestic repression, and they inherently could not maintain cooperative relations with democracies in the long term. ${ }^{22}$

\footnotetext{
${ }^{16}$ G. John Ikenberry, Liberal Leviathan: The Origins, Crisis, and Transformation of the American World Order (Princeton, NJ, 2011), 67-78; Tony Smith, Why Wilson Matters: The Origin of American Liberal Internationalism and Its Crisis Today (Princeton, NJ, 2017), xi, 11-2.

${ }^{17}$ See Alan Brinkley, Liberalism and Its Discontents (Cambridge, MA, 1998), ix; Delton, Rethinking the 1950s; and G. Calvin Mackenzie and Robert Weisbrot, The Liberal Hour: Washington and the Politics of Change in the 1960s (New York, 2008), 11-41.

${ }^{18}$ For some major contemporaneous works that espoused a liberal consensus, see Richard Hofstadter, The American Political Tradition and the Men Who Made It (New York, 1948); Louis Hartz, The Liberal Tradition in America: An Interpretation of American Political Thought since the Revolution (New York, 1955); and Daniel Bell, The End of Ideology: On the Exhaustion of Political Ideas in the Fifties (Glencoe, IL, 1960). For more on the political culture of liberal consensus and the conservative revolt against it, see Rick Perlstein, Before the Storm: Barry Goldwater and the Unmaking of the American Consensus (New York, 2001).

${ }^{19}$ Ciepley, Liberalism in the Shadow of Totalitarianism, 2; Schlesinger, Vital Center, 59-64.

${ }^{20}$ Abbott Gleason, Totalitarianism: The Inner History of the Cold War (New York, 1995), 72-6; Bell, "What Is Liberalism?" 699.

${ }^{21}$ For background on evolving interpretations of totalitarianism, see Gleason, Totalitarianism; Anson Rabinbach, “Totalitarianism Revisited," Dissent 53, no. 3 (Summer 2006): 77-84; and Michael Geyer and Sheila Fitzpatrick, eds., Beyond Totalitarianism: Stalinism and Nazism Compared (New York, 2008).

${ }^{22}$ Gary Dorrien, Imperial Designs: Neoconservatism and the New Pax Americana (New York, 2004), 120-1; Smith, Why Wilson Matters, 10; Carl J. Friedrich and Zbigniew K. Brzezinski, Totalitarian Dictatorship and Autocracy (Cambridge, MA, 1956).
} 
Liberals like Schlesinger conceived of the Cold War not merely as a geopolitical conflict but as a struggle to defend liberalism from totalitarianism, the "defining Other" of postwar liberalism. ${ }^{23}$ If liberalism sought to defend individual rights and government by consent of the people, there could be no greater foe than totalitarianism. ${ }^{24}$ In the process of opposing totalitarianism, Cold War liberals redefined their creed as more moderate, anti-utopian, and individualistic, distancing it from Progressive and New Deal optimism about enlightened government. ${ }^{25}$

The pinnacle of modern liberal confidence in the power of government to improve people's lives and defend their rights came with President Lyndon Baines Johnson's Great Society and alliance with the civil rights movement. ${ }^{26}$ The next several decades, however, severely tested this optimism. The Vietnam War undermined the Great Society and delegitimized Johnson's presidency. New Left activists as varied as black nationalists, radical feminists, and antiwar protestors surged into prominence in the late 1960s and 1970s. They shared a contempt for liberalism, which they critiqued as too moderate, elitist, and capitalist to dismantle oppressive systems. ${ }^{27}$ Meanwhile, a conservative movement ascended in the Republican Party, culminating in Ronald Reagan's election in 1980. This movement shattered the ostensible liberal consensus and ushered in a new politics of free market economics, backlash against social change, and skepticism toward government intervention. ${ }^{28}$ The Democratic Party foundered, losing key demographics like the white working class and winning only one presidential election between Johnson and Clinton. ${ }^{29}$

Along with these changes came a rejection of the hawkish liberalism of the Cold War Vital Center. After Vietnam, liberal thinkers became far more skeptical of U.S. military interventions and more likely to see the United States as a harmful, imperialist power. ${ }^{30}$ As liberals soured on the Cold War, human rights became a new foreign policy priority, as seen in Jimmy Carter's embrace of human rights and the rise of anti-apartheid as a major liberal cause. ${ }^{31}$ Most liberal intellectuals, including Schlesinger, opposed the 1991 Gulf War, viewing it as a realpolitik conflict that sought to preserve access to oil and safeguard the corrupt theocrats of Saudi Arabia. ${ }^{32}$

In the 1980s and 1990s, many Democrats responded to these crises by eschewing the liberal label altogether, which conservatives and leftists now used as a pejorative, and charting a more centrist path. ${ }^{33}$ Centered around the Democratic Leadership Council (DLC), these Democrats believed that the political spectrum had shifted rightward in recent years and that the electorate viewed the party as weak on defense, overly redistributionist, and out of touch with ordinary people's values. The DLC tried to hew closer to centrist positions on domestic issues by endorsing a more assertive and pro-democratic foreign policy. ${ }^{34}$ As president, Clinton roughly

\footnotetext{
${ }^{23}$ Ciepley, Liberalism in the Shadow of Totalitarianism, 1; Gleason, Totalitarianism, 69-70.

${ }^{24}$ Gleason, Totalitarianism, 76-8; Schlesinger, Vital Center, 51-67.

${ }^{25}$ Ciepley, Liberalism in the Shadow of Totalitarianism, 2, 8; Ira Katznelson, Desolation and Enlightenment: Political Knowledge after Total War, Totalitarianism, and the Holocaust (New York, 2003); Schlesinger, Vital Center, 51-67.

${ }^{26}$ Mackenzie and Weisbrot, Liberal Hour, 84-184.

${ }^{27}$ Van Gosse, Rethinking the New Left: An Interpretive History (New York, 2005), 1-9; Kloppenberg, Virtues of Liberalism, 148; Ryan, Making of Modern Liberalism, 130.

${ }^{28}$ Gregory L. Schneider, The Conservative Century: From Reaction to Revolution (Lanham, MD, 2009), 91-153.

${ }^{29}$ Mackenzie and Weisbrot, Liberal Hour, 8.

${ }^{30}$ Jacob Heilbrunn, They Knew They Were Right: The Rise of the Neocons (New York, 2008), 49.

${ }^{31} \mathrm{Hal}$ Brands, Making the Unipolar Moment: U.S. Foreign Policy and the Rise of the Post-Cold War Order (Ithaca, NY, 2016), 39-53; Heilbrunn, They Knew They Were Right, 113-4.

${ }^{32}$ Arthur Schlesinger Jr., for example, argued against the war on these grounds. See Derek Chollet and James Goldgeier, America Between the Wars: From 11/9 to 9/11: The Misunderstood Years Between the Fall of the Berlin Wall and the Start of the War on Terror (New York, 2008), 197.

${ }^{33}$ Freeden and Stears, "Liberalism," 344; Sean Wilentz, The Age of Reagan: A History, 1974-2008 (New York, 2008), 271.

${ }^{34}$ Julian E. Zelizer, Arsenal of Democracy: The Politics of National Security-From World War II to the War on Terrorism (New York, 2010), 378-9; Jon F. Hale, “The Making of the New Democrats,” Political Science Quarterly 110, no. 2 (Summer 1995): 207-32, here 207-13.
} 
followed the DLC strategy by appropriating conservative rhetoric, for instance by declaring in 1996 that "the era of big government is over." He presented his moderate liberalism as a middle ground between conservatives and the left, although many liberals believed his positions on issues like welfare and free trade betrayed the progressive heritage of Roosevelt and Johnson. ${ }^{35}$

The 1990s marked a pivotal shift for modern U.S. liberalism in one additional sense: the rise of humanitarian interventionism and the liberal reconciliation with U.S. power as a force for good. In the 1990s, a wave of genocides and humanitarian disasters erupted, and the United States intervened in Northern Iraq, Somalia, Bosnia, and Kosovo. To defend these interventions, theorists and politicians developed a doctrine of humanitarian intervention, arguing that a state's sovereignty hinged on whether it protected the rights and lives of its citizens. If it committed genocide or other massive crimes, outside states could intervene, with force if necessary, to stop these crimes and restore governance. ${ }^{36}$ The legal concept of a "responsibility to protect" (R2P), in which the U.N. Security Council may endorse armed intervention to stop major human rights violations, became formalized in international law in the early $2000 \mathrm{~s}^{37}$ Humanitarian interventionists such as Power and Ignatieff argued that the United States could not intervene in every crisis but that it should stop massive atrocities when the costs would be moderate and the chances of success were high. ${ }^{38}$ The war in the former Yugoslavia catalyzed liberals' willingness to support the use of U.S. power, marking a major shift from the post-Vietnam malaise. ${ }^{39}$

Liberal thinkers also emerged from the 1990s with a deeper skepticism of the ability and willingness of European allies and the United Nations to handle humanitarian crises alone. These thinkers emerged from the 1990s with a deepened sense of moral urgency for confronting tyrants and protecting the oppressed. At the same time, they faulted Clinton for his concessions to conservatism at home and his frequent irresolution on humanitarian crises abroad. Reviving liberalism, they believed, required rejecting Clinton's cautious centrism in favor of confident reformism and the embrace of the liberal missions of anti-totalitarianism and humanitarian interventionism abroad.

\section{The Liberal War on Terror and the New Vital Center}

Many political scholars hold that the boundaries of liberal thought, and liberals as individuals, should be "characterized by the sum of the arguments that have been classified as liberal, and recognized as such by other self-proclaimed liberals" in a given context. Understanding liberalism in this way requires looking at actors who constructed and contested its meaning and tried to adapt their versions of liberalism to an evolving set of real-world problems. ${ }^{40}$ This "contextualist" method is useful for understanding the New Vital Center because most of the actors in this story defined themselves as liberal.

Yet the messy but important cross-ideological alliances that often form in specific contexts can be overlooked if only those actors who identify as liberals are considered. In particular,

\footnotetext{
${ }^{35}$ Kloppenberg, Virtues of Liberalism, 8; Wilentz, Age of Reagan, 324.

${ }^{36}$ Michael Ignatieff, "Intervention and State Failure," Dissent 49, no. 1 (Winter 2002): 114-23; Michael Walzer, "The Politics of Rescue," Social Research 62, no. 1 (Spring 1995): 53-66, here 54-6.

${ }^{37}$ Responsibility to Protect gained legal standing at the U.N. General Assembly's 2005 World Summit. See United Nations General Assembly, 2005 World Summit Outcome, Sept. 16, 2005, A/60/L.1, https://www.un.org/ en/development/desa/population/migration/generalassembly/docs/globalcompact/A_RES_60_1.pdf (accessed Aug. 5, 2021), 30; Mazower, Governing the World, 385-90.

${ }^{38}$ Michael Cotey Morgan, "Michael Ignatieff: Idealism and the Challenge of the 'Lesser Evil," International Journal 61, no. 4 (Autumn 2006): 971-85, here 976-80; Gareth Evans and Mohamed Sahnoun, "The Responsibility to Protect," Foreign Affairs 81, no. 6 (Nov.-Dec. 2002): 99-110, here 103-5.

${ }^{39}$ Heilbrunn, They Knew They Were Right, 223-5.

${ }^{40}$ Bell, "What Is Liberalism?" 682, 687-9. See also Raymond Geuss, "Liberalism and Its Discontents," Political Theory 30, no. 3 (June 2002): 320-38, here 323-7.
} 
figures such as Walzer, Gitlin, and Kazin came to play important roles in New Vital Center liberalism without identifying as liberals. These intellectuals had deep histories in progressive and/or leftist politics, and they continued to identify with these traditions in the early 2000s. Both Kazin and Walzer had served as co-editors of Dissent, a magazine founded by left-wing intellectuals in the 1950s to criticize both U.S. liberals for their tepid support for social justice and Soviet communism for its many crimes. ${ }^{41}$ Walzer had long criticized mainstream liberalism for its devaluing of community and the common good in favor of excessive individualism. ${ }^{42}$ Kazin and Gitlin had been active in Students for a Democratic Society (SDS) in the 1960s and later joined the Democratic Socialists of America. ${ }^{43}$ Their increasing dissatisfaction with leftist thought in the 1990s and early 2000s drove them closer to the visions of liberal universalism developed by self-identified liberals like Packer and Berman. Walzer, Gitlin, Kazin, and others can be seen as "refugees from the left," who found meaningful commonalities with liberal allies. These refugees believed that a leftist worldview required commitment to universalist value systems, resistance to tyranny, and solidarity with the oppressed of the world, no matter their race, nationality, or religion. They also believed it required a willingness at times to support the use of U.S. power to achieve these ends. ${ }^{44}$ The events of $9 / 11$, and the left's response, formed a breaking point for these refugees, solidifying their intellectual coalition with the New Vital Center liberals.

The New Vital Center project aimed to redefine and reposition liberalism in a time of flux, fear, and opportunity. These thinkers believed that Bush had provided the dominant vision of U.S. values and the War on Terror following 9/11. In their view, the Democrats were riding conservative coattails, trying to look tough and patriotic, but they lacked vision and feared calling themselves liberals. The ideological left offered little more than blanket condemnation of the United States, unrealistic plans to counter terrorism, such as ending U.S. support for Israel and Middle Eastern autocracies and withdrawing U.S. troops from the region, and reflexive criticism of patriotism, all of which marginalized their political influence. ${ }^{45}$

This reinvention first required understanding what had gone wrong with liberalism in the last several decades. Writers such as Packer, Berman, and Beinart held that since the 1960s, liberals had retreated from mainstream politics into big cities and universities where they obsessed over "narrower causes, defined not by any universal principles but along the lines of identity." 46 According to Packer, liberals had fallen for postmodernist theory that "prefers dancing circles around important questions to the risk of trying to answer them," as well as multicultural battles over "group grievances." Packer listed the flaws of modern liberalism in unrelenting terms: "The reluctance to make judgments, the finely ironic habits of thought, the reflexive contempt for patriotism, the suspicion of uniforms and military qualities, the sentimentality about oppressed peoples, the embarrassment with phrases like 'democratic values' and 'Western civilization."”47

\footnotetext{
${ }^{41}$ Joanne Barkan, "Cold War Liberals and the Birth of Dissent," Dissent 53, no. 3 (Summer 2006): 95-102, here 95.

${ }^{42}$ Walzer's criticism has been labelled "communitarianism," although he never explicitly adopted this label. See Michael Walzer, "The Communitarian Critique of Liberalism," Political Theory 18, no. 1 (Feb. 1990): 6-23, here 9-11.

${ }^{43}$ On Kazin's politics, see Kate Aronoff, Peter Dreier, and Michael Kazin, eds., We Own the Future: Democratic Socialism-American Style (New York, 2020), 5-11.

${ }^{44}$ Michael Walzer, "Terror and the Response," Dissent 49, no. 1 (Winter 2002): 5-15, here 5; Michael Walzer, "Can There Be a Decent Left?" Dissent 49, no. 2 (Spring 2002): 19-23, here 22.

${ }^{45}$ Packer, "America's Age of Empire," 35. For an example of the kind of leftist thought on the War on Terror that liberals found unrealistic, see Howard Zinn, "A Just Cause, Not a Just War," The Progressive 65, no. 12 (Dec. 2001): $16-9$.

${ }^{46}$ George Packer, "Introduction: Living Up to It," in The Fight Is for Democracy: Winning the War of Ideas in America and the World, ed. George Packer (New York, 2003), 1-19, here 11; Thomas Cushman, "Introduction: The Liberal-Humanitarian Case for War in Iraq," in A Matter of Principle: Humanitarian Arguments for War in Iraq, ed. Thomas Cushman (Berkeley, CA, 2005), 1-26, here 6.

${ }^{47}$ Packer, "Introduction," 11-3, 16.
} 
Without a unifying liberal vision, these liberals believed, the Democratic Party had collapsed into a collection of interest groups on issues such as health care, gay rights, and environmentalism. ${ }^{48}$ In the meantime, Packer claimed, conservatives "took up the universalist language of reason, freedom, and truth." The combination of the conservative ascension and the liberals' abandonment of their own creed left the country divided, purposeless, and complacent. In Packer's words, "September 11 came as an immense slap to this immense complacency." 49 Following 9/11, conservatives squandered the opportunity to rally the people to collective efforts against extremism, asking them to do little more than wave flags and acquiesce to Bush's decisions. As Packer argued, "Conservatives today have no concept of the public good. They see Americans as investors and consumers, not citizens."

Meanwhile, they claimed, Bush's domestic policies accelerated the corruption of society, including growing income inequality, the takeover of politics by outside money, and the erosion of civil liberties. ${ }^{51}$ Beinart, for instance, noted that Bush had cut taxes as the United States began a global conflict, showing his economic incompetence and unwillingness to rally the people to a common purpose. ${ }^{52}$ They argued that Bush's foreign policy undermined U.S. moral capital by devaluing international law, employing controversial detention and interrogation policies, and abandoning multilateral institutions like the Kyoto Protocol and the International Criminal Court. ${ }^{53}$

To rebuild liberalism, these intellectuals believed they needed to recommit to more universalistic and communal conceptions of liberalism. This re-emergence of the optimistic-universal version of liberalism formed the core of the New Vital Center project. The U.S. victory in the Cold War, and the surge in new democracies in Latin America, Eastern Europe, and East Asia in the 1980s and 1990s, encouraged this belief. Starting with foreign policy, Tomasky contended that liberals and Democrats should become "the party of world democracy," working with allies to "spread democratic values and freedoms, to surround and neutralize terror and the fundamentalism from which it grows." ${ }^{54}$ Liberals should remain skeptical of militarism, Beinart and Berman argued, but they must be willing to support the use of force against rogue states and terrorists. ${ }^{55}$

These liberals believed that following a universalistic path obligated the United States to embrace a foreign policy based on human rights, especially for women and minorities, and democracy. ${ }^{56}$ It required that the United States stop coddling Arab dictators whose tyranny fomented extremism and increase aid to assist Middle Eastern development. ${ }^{57}$ Berman claimed

\footnotetext{
${ }^{48}$ Beinart, "Fighting Faith," 21.

${ }^{49}$ Packer, "Introduction," $11,16$.

${ }^{50}$ Ibid., 9, 17. See also Todd Gitlin, "Symposium: Drums of War, Calls for Peace," Dissent 50, no. 1 (Winter 2003): 5-17, here 10-1; Paul Berman, interview by Wen Stephenson, PBS Frontline, Mar. 24-31, 2003, https:// www.pbs.org/wgbh/pages/frontline/shows/blair/liberal/berman.html (accessed Aug. 5, 2021).

${ }^{51}$ Packer, "Introduction," 19; Marc Cooper, "A Year Later: What the Right and Left Haven't Learned," in The Iraq War Reader: History, Documents, Opinions, eds. Micah L. Sifry and Christopher Cerf (New York, 2003), 225-8, here 226-7; Michael Ignatieff, "Friends Disunited," The Guardian, Mar. 24, 2003, https://www.theguardian.com/politics/2003/mar/24/iraq.world (accessed Aug. 5, 2021).

${ }^{52}$ Beinart, "Fighting Faith,” 23; Packer, “America's Age of Empire," 35.

${ }^{53}$ Gitlin, "Symposium: Drums of War, Calls for Peace," 10-1; Packer, "America's Age of Empire," 36-7; Paul Berman, "Thirteen Observations on a Very Unlucky Predicament," in The Fight Is for Democracy: Winning the War of Ideas in America and the World, ed. George Packer (New York, 2003), 265-90, here 288; Samantha Power, "Force Full: Bush's Illiberal Power," The New Republic, Mar. 3, 2003, https://newrepublic.com/article/ 66759/srebenica-liberalism-balkan-united-nations (accessed Aug. 5, 2021).

${ }^{54}$ Tomasky, "Between Cheney and Chomsky," 43.

${ }^{55}$ Beinart, "Fighting Faith," 22; Berman interview.

${ }^{56}$ Walzer, "Can There Be a Decent Left?" 22; Packer, "Introduction," 17; Tomasky, "Between Cheney and Chomsky," 42; Michael Kazin, “A Patriotic Left,” Dissent 49, no. 4 (Fall 2002): 41-4; Power, "Force Full.”

${ }^{57}$ Tomasky, "Between Cheney and Chomsky," 43; Todd Gitlin, "Liberalism's Patriotic Vision," New York Times, Sept. 5, 2002, A23; Packer, “America's Age of Empire,” 38.
} 
that this defense of human rights would capture the spirit of earlier generations of liberals and socialists who held that "everyone, all over the world, would some day want to live according to the same fundamental values, and ought to be helped to do so." ${ }^{58}$ Packer echoed this commitment to universalism, arguing that "a liberal foreign policy starts with the idea that the things U.S. liberals want for themselves and for their own country-liberty and equality ensured by collective actions ... should be America's goal for the rest of the world." ${ }^{\text {" }}$ Virtually all of these thinkers supported the U.S. war in Afghanistan, which they saw as both a security measure to destroy terrorist safe havens and a humanitarian act against the brutal, misogynistic Taliban regime. ${ }^{60}$

Many New Vital Center liberals concluded that this reformed foreign policy required the United States to embrace nation-building or even a quasi-imperial role, a project they had begun to warm to in the 1990s as a means of restoring functioning governance after U.S. interventions. ${ }^{61}$ After 9/11, Ignatieff, Packer, and others argued that efforts to rebuild and democratize places like Iraq and Afghanistan would fail without a commitment to long-term nation-building - at least ten years for Iraq, in Ignatieff s prediction. As he put it, the United States had "an urgent state interest ... to rebuild failed states so that they cease to be national security threats." ${ }^{62}$ He viewed this "imperial policing" as a necessary adaptation to the globalized, post-9/11 world where the consequences of state failure, from refugee flows to terrorism, did not stay within national boundaries. ${ }^{63}$ While few New Vital Center liberals embraced the imperial label, they recognized that championing liberal values and defending the homeland would require expansive involvement in troubled areas of the world. ${ }^{64}$

The fight for democracy and human rights abroad would not succeed, liberal intellectuals argued, without political reforms at home that challenged rather than conciliated conservative dominance. Most of these thinkers rejected the neoliberal "Washington Consensus" of privatization and unrestrained markets that both major parties had endorsed in the 1990s. They claimed this notion of the citizen as economic actor alone had fostered hyper-individualism and radical inequality. ${ }^{65}$ Packer and others recommended a host of reforms: environmental protections, alternative energy, the restoration of labor rights, progressive taxation, checks on capital flow and privatization, and greater limits on corporate influence in politics. These reforms would bring about a fairer society, reduce dependence on Middle Eastern oil, and renew Americans' faith in democracy as a global force. ${ }^{66}$

Liberals rethought their relationship to patriotism in order to reclaim these values from the right and distance themselves from the left. This required reinterpreting fundamental aspects of

\footnotetext{
${ }^{58}$ Paul Berman, “A Friendly Drink in a Time of War,” Dissent 51, no. 1 (Winter 2004): 56-8, here 57.

${ }^{59}$ Packer, "America's Age of Empire," 38.

${ }^{60}$ Walzer, "Can There Be a Decent Left?" 19; William Galston, "Iraq and Just War: A Symposium,” Pew Research Center, Sept. 30, 2002, https://www.pewforum.org/2002/09/30/iraq-and-just-war-a-symposium/ (accessed Aug. 5, 2021); Paul Berman, "Terror and Liberalism," The American Prospect, Oct. 22, 2001, 18-23, here 20.

${ }^{61}$ Samantha Power, "Raising the Cost of Genocide," Dissent 49, no. 2 (Spring 2002): 85-95; David Rieff, “A New Age of Liberal Imperialism?" World Policy Journal 16, no. 2 (Summer 1999): 1-10, here 8-10; Ignatieff, "Intervention and State Failure," 118-20; Walzer, "Politics of Rescue," 57-61; Packer, "America's Age of Empire," 38.

${ }^{62}$ Ignatieff, "Intervention and State Failure," 114.

${ }^{63}$ Michael Ignatieff, Empire Lite: Nation-Building in Bosnia, Kosovo and Afghanistan (Toronto, 2006), 11; Power, "Raising the Cost of Genocide," 90.

${ }^{64}$ On the intellectual history of liberal imperialism, see Pitts, Turn to Empire; and Uday Singh Mehta, Liberalism and Empire: A Study in Nineteenth-Century British Liberal Thought (Chicago, 1999).

${ }^{65}$ Power, "Force Full"; Packer, "Introduction," 9-10. For an overview of neoliberalism in the United States, see David Harvey, A Brief History of Neoliberalism (New York, 2005).

${ }^{66}$ Packer, "America's Age of Empire," 38; Ignatieff, "Friends Disunited"; Gitlin, "Liberalism's Patriotic Vision," A23; Thomas L. Friedman, "Bush, Iraq and Sister Souljah," New York Times, Dec. 8, 2002, C15; Peter Beinart, "War Paths," The New Republic, Feb. 18, 2002, 6.
} 
liberalism itself. As liberals, these figures identified as cosmopolitan and open-minded, which made many of them uncomfortable with displays of patriotism. They tended to view patriotism as a tool of the elites and a screen for racism, raw capitalism, and imperialist wars like Vietnam, which many of them had protested against. However, the rise of humanitarian interventionism in the 1990s had caused many liberals to see their country as a potential force for good. The feeling of collective shock, mourning, and anger on 9/11 accelerated this shift. Packer, for instance, recalled feeling an unprecedented sense of connection with other New Yorkers on $9 / 11$ as they rallied to help and comfort each other. He spent two days after 9/11 waiting in line to donate blood and talking with ordinary people and rescue workers, noting a collective desire to serve. On that day, he declared, "We became citizens." ${ }^{67}$ Berman was also in New York on $9 / 11$, and he observed "a gratifying scene of communal solidarity" in a city that represented "the whole of mankind." ${ }^{68}$ This liberal surge of patriotism fit the general outpouring of patriotic feeling after the attacks, and liberals hoped to channel patriotism toward progressive ends before it faded or was diverted toward nationalistic backlash. Gitlin, for instance, concluded that the post-9/11 era offered a "superb time to crack the jingoists' claims to a monopoly of patriotic virtue." 69

The historian Michael Kazin took up the reconciling of liberalism and patriotism with particular ardor. In a 2002 essay for Dissent, Kazin confessed, "I love my country," especially the "civic ideals" of "social equality, individual liberty, a populist democracy—and the unending struggle to put their laudable, if often contradictory, claims into practice." For Kazin, liberals should pursue these ideals earnestly rather than "dismissing them as fatally compromised by the racism of the founders or the abusiveness of flag-waving vigilantes." ${ }^{70}$ Rejecting patriotism only marginalized liberals and ceded the moral high ground to the right. New Vital Center liberals embraced "civic nationalism," rooted in ideals and progress rather than blood and soil, in which "the most effective way to love the country is to fight like hell to change it." This form of patriotism would be based, in Kazin's words, "in pride in the first nation organized around a set of social beliefs rather than a shared geography and history." 71

Another major theme in the New Vital Center's vision of the War on Terror was the liberal mission of anti-totalitarianism. Numerous liberals cast Islamic extremists like Taliban and al-Qaeda as well as rogue states like Iraq as a new totalitarian menace to liberal democracy. Berman led the development of this idea. In his influential Terror and Liberalism (2003), he argued that extreme Islamists like the Egyptian Sayyid Qutb aimed to subject all human life to theocratic rule, rejecting human rights, women's liberation, and secular government while enforcing an adherence to religious law that would extinguish the sphere of private individual life. Berman contended that the new totalitarians, like the Nazis and Soviets, created cults of personality, worshipped apocalyptic violence, and denounced liberal values. ${ }^{72}$ In a similar vein, Packer summarized totalitarianism as "a revolt against liberalism."73

Thus, for Berman and other liberals, the War on Terror's true foe was "Muslim totalitarianism," or the linked threats of Baathism and radical Islam. 9/11 did not represent a "clash of civilizations," Berman claimed, but the escalation of a struggle between essentially modern ideologies, which made the War on Terror the sequel to World War II and the Cold War. He and

\footnotetext{
${ }^{67}$ Packer, "Introduction," 1-4. See also Ignatieff, "Friends Disunited."

${ }^{68}$ Paul Berman, "Under the Bridge," The New Republic, Sept. 24, 2001, 12-3.

${ }^{69}$ Gitlin, "Liberalism's Patriotic Vision," A23.

${ }^{70}$ Kazin, "Patriotic Left," 42, 61. See also David Talbot, “The Making of a Hawk," Salon, Jan. 3, 2002, https:// www.salon.com/2002/01/03/hawk/ (accessed Aug. 5, 2021); Todd Gitlin, "Blaming America First," Mother Jones, Jan./Feb. 2002, 22-5.

${ }^{71}$ Kazin, "Patriotic Left," 41-4. Kazin elaborated on these themes in Michael Kazin and Joseph A. McCartin, eds., Americanism: New Perspectives on the History of an Ideal (Chapel Hill, NC, 2006).

${ }^{72}$ Paul Berman, Terror and Liberalism (New York, 2003), 46-50, 68-71, 78-84.

${ }^{73}$ George Packer, The Assassins' Gate: America in Iraq (New York, 2005), 48.
} 
others contended that the Bush administration had missed the true ideological nature of the War on Terror because of their laser-focus on national security. Liberals, meanwhile, had naively assumed that the great ideological struggles of history had ended. With their conception of human beings as rational, Berman held, liberals tend to search for comprehensible "grievances" or "a hidden rationality" that would make someone hate the United States to a homicidal degree. Many of them, he argued, believed that removing U.S. troops from Saudi Arabia or ending support for Israel would stem radical Islam. ${ }^{74}$

Berman dissented from all of these ideas. He argued that Iraqi dictator Saddam Hussein, al-Qaeda, and other extremists did not hate the United States simply because of its foreign policy; like the European totalitarians, they hated its liberal political ideals: pluralism, the liberation of women, individual rights, religious toleration, and constitutional government. ${ }^{75}$ Berman summarized this point: "America's crime, its real crime, is to be America herself ... America's crime is to show that liberal society can thrive and anti-liberal society cannot. This is the whip that drives the anti-liberal movements to their fury." ${ }^{76}$ Thus, the New Vital Center project needed to revive the historical liberal mission of opposing totalitarianism, just like the early Cold War liberals. Anti-totalitarianism would be their "north star," in Beinart's phrasing, and this mission would renew their confidence in their own ideals. ${ }^{77}$

Members of the New Vital Center unanimously agreed that their project required a firm repudiation of the ideological left, especially its responses to 9/11. Leftists like the historian Howard Zinn, the cultural theorist Edward Said, and the linguist Noam Chomsky opposed not just the war in Iraq but the entire War on Terror, including the conflict in Afghanistan. According to a 2002 "Statement of Conscience" signed by Zinn, Chomsky, Said, and other leftleaning intellectuals, the United States had responded to $9 / 11$ with "a spirit of revenge" and a "simplistic script of good vs. evil." Zin and Chomsky argued that while 9/11 was a "crime against humanity," so were the bombings of Vietnam and Afghanistan. ${ }^{79}$ In political scientist Chalmers Johnson's terminology, Americans should understand terrorism as "blowback" from imperialism, the inequities of globalization, and U.S. support for dictators. ${ }^{80}$ Many leftists identified an element of comeuppance in 9/11 for a history of imperial violence. Chomsky, for instance, wrote: "On September 11, for the first time, a western country was subjected on home soil to a horrendous terrorist attack of a kind all too familiar to victims of Western power."

For the left, 9/11 reflected the failure of U.S. hegemony in the Middle East, which meant that the United States should withdraw its forces from most overseas bases; abandon support for Israel, Egypt, and other problematic states; and reflect on the harms it had caused in the

\footnotetext{
${ }^{74}$ Berman, Terror and Liberalism, 121-44.

${ }^{75}$ Berman, "Thirteen Observations on a Very Unlucky Predicament," 284-6; Christopher Hitchens, "Against Rationalization," in Hitchens and His Critics: Terror, Iraq, and the Left, eds. Simon Cottee and Thomas Cushman (New York, 2008), 44-6, here 45-6.

${ }^{76}$ Berman, Terror and Liberalism, 21; Beinart, "Fighting Faith," 22.

${ }^{77}$ Beinart, "Fighting Faith," 22-3; Packer, "Introduction," 15.

${ }^{78}$ Not in Our Name, "Statement of Conscience," The World Can't Wait!, 2002, http://www.worldcantwait.net/ index.php/about-mainmenu-2/about-world-cant-wait-mainmenu-215/history-of-world-can-t-wait/8232-not-in-ourname-statement-of-conscience (accessed Aug. 5, 2021).

${ }^{79}$ Zinn, "Just Cause," 16; Not in Our Name, "Statement of Conscience."

${ }^{80}$ Chalmers Johnson, "Blowback," Nation, Oct. 15, 2001, 13-5. See also Noam Chomsky, "Power in the Global Arena,” New Left Review 1, no. 230 (July/Aug. 1998): 3-27, here 5-6, 27.

${ }^{81}$ Noam Chomsky, "Drain the Swamp and There Will Be No More Mosquitos," The Guardian, Sept. 8, 2002, https:/www.theguardian.com/politics/2002/sep/09/foreignpolicy.iraq (accessed Aug. 5, 2021); Not in Our Name, "Statement of Conscience"; Noam Chomsky, 9-11 (New York, 2001), 35; Howard Zinn quoted in Simon Cottee and Thomas Cushman, "Introduction: Terror, Iraq, and the Left," in Christopher Hitchens and His Critics: Terror, Iraq, and the Left, eds. Simon Cottee and Thomas Cushman (New York, 2008), 1-36, here 12. See also Howard Zinn, “The Others,” Nation, Feb. 11, 2002, 16-20, here 16-7.
} 
world. ${ }^{82}$ Leftists argued that the United States needed to address what Zinn called the "justified grievances felt by millions of people who would not themselves engage in terrorism but from whose ranks terrorists spring." ${ }^{\prime 3}$ In general, leftists questioned the idea that U.S. power could be used for moral ends, citing a history of aggression, the killing of civilians, and support for dictators. $^{84}$

For political as well as intellectual reasons, the thinkers of the New Vital Center felt they had to distance themselves from the left in order to combat the conservative tactic of discrediting liberals by branding them as unpatriotic radicals. Liberal thinkers criticized the left's tendency to treat the United States as the greatest threat to world peace and the cause of all the world's problems while drawing moral equivalence between it and its enemies. ${ }^{85}$ Regarding 9/11, Walzer argued that many leftists had "failed to register the horror of the attack or acknowledge the human pain it caused" and reacted with "barely concealed glee that the imperial state had finally gotten what it deserved." ${ }^{\prime 6}$ Many on the left, Berman and Walzer argued, sympathized instinctively with countries who defied the United States, especially when those states framed their defiance as anti-imperialism. They downplayed the enormous crimes of terrorists and rogue states as well as their deeply regressive positions on issues the left cared about. ${ }^{87}$ These views of the War on Terror betrayed the solidarity the left should show with the oppressed. $^{88}$

For these liberal thinkers, the left lacked credible policy ideas for confronting terrorism and rogue states. Power contended that the left's "squeamish moral relativism" prevented them from endorsing almost any U.S. military action, even against genocide or the perpetrators of 9/11. ${ }^{89}$ Packer lamented that the left saw "no useful American role in the world order other than disarmament and withdrawal." 90 The left, Walzer claimed, wanted to "pretend that there really isn't a serious threat out there," but its moral absolutism and dread of U.S. power offered no realistic way forward. ${ }^{91}$

Rejecting the left ultimately enabled U.S. liberals to further reconcile themselves to patriotism and the use of U.S. power for positive ends. To them, the United States was neither the redeemer nation that the right celebrated nor the evil empire that the left deplored. If guided by the right ideas, they held that it could counter much evil and build a better world. ${ }^{92}$ Liberals, however, could not shape foreign policy without making themselves more credible and patriotic

\footnotetext{
${ }^{82}$ Zinn, "Just Cause," 18; Mahmood Mamdani, Good Muslim, Bad Muslim: America, the Cold War, and the Roots of Terror (New York, 2004), 11-3; Johnson, “Blowback,” 14-5; Editorial, “One Year Later,” Nation, Sept. 23, 2002, 3-5.

${ }^{83}$ Zinn, "Just Cause," 17-9. See also Alexander Cockburn, “The Tenth Crusade," Nation, Sept. 23, $2002,9$.

${ }^{84}$ For a collection of left-leaning response to $9 / 11$ and the War on Terror, see Beyond September 11: An Anthology of Dissent, ed. Phil Scraton (Sterling, VA, 2002).

${ }^{85}$ Berman, "Friendly Drink in a Time of War," 56-8; Gitlin, "Liberalism’s Patriotic Vision," 123; David Rieff, interview by Wen Stephenson, PBS Frontline, Mar. 25, 2003, https:/www.pbs.org/wgbh/pages/frontline/shows/ blair/liberal/rieff.html (accessed Aug. 5, 2021); Peter Beinart, "Fault Lines," The New Republic, Oct. 1, $2001,8$.

${ }^{86}$ Walzer, "Can There Be a Decent Left?" 20.

${ }^{87}$ Berman, Terror and Liberalism, 151; Walzer, "Can There Be a Decent Left?" 19; Mitchell Cohen, "In the Murk of It: Iraq Reconsidered," in A Matter of Principle: Humanitarian Arguments for War in Iraq, ed. Thomas Cushman (Berkeley, CA, 2005), 76-92, here 77.

${ }^{88}$ Michael Ignatieff, "Why Are We in Iraq? (And Liberia? And Afghanistan?)," New York Times Magazine, Sept. 7, 2003, 85; Cushman, "Introduction," 12; Christopher Hitchens, "Taking Sides," in Hitchens and His Critics: Terror, Iraq, and the Left, eds. Simon Cottee and Thomas Cushman (New York, 2008), 101-4, here 104.

${ }^{89}$ Power, "Force Full." See also Talbot, "Making of a Hawk."

${ }^{90}$ Packer, "America's Age of Empire," 38.

${ }^{91}$ Michael Walzer, "The Right Way," New York Review of Books, Mar. 13, 2003, 37; Gitlin, "Blaming America First," 22-3.

${ }^{92}$ Walzer, "Can There Be a Decent Left?" 20-2; Tomasky, "Between Cheney and Chomsky," 44-5; Ignatieff, "Friends Disunited."
} 
participants in national life. Carving out this new role would be impossible if they tolerated what the sociologist Thomas Cushman called the "elemental anti-Americanism of the left." 93

\section{The Liberal Split over the Iraq War}

While liberals united around this vision of a revived liberalism, they diverged on the invasion of Iraq. Some scholars have accused pro-war liberals of naively parroting Bush's case for war, thereby facilitating a disastrous invasion. Historian Tony Judt, for instance, argues that liberal hawks accepted the neoconservatives' "binary division of the world" and "invented ideological and moral cover for war and war crimes and proffered that cover to their political enemies." Indeed, pro-war liberals such as Packer, Ignatieff, and Berman shared some positions with neoconservatives like Undersecretary of Defense Paul Wolfowitz. Pro-war elements of the New Vital Center may have felt more anxious than neoconservatives about supporting the invasion of Iraq, but they nonetheless backed the war and helped marginalize the antiwar left. They also shared the neoconservatives' somewhat blithe ethical universalism and failure to think through the potential consequences of U.S. military action.

The New Vital Center liberals held that U.S. power must be exercised through alliances and multilateral institutions and within international law, in stark contrast to the neoconservative obsession with U.S. global hegemony and skepticism of international institutions. ${ }^{95}$ If humanitarianism for the Bush administration was largely a post hoc justification for war, it deeply motivated these liberal thinkers. They also dissented from the neoconservative doctrine of unilateral preventive war, which New York Times columnist Bill Keller described as "a determination to keep America an unchallenged superpower, a willingness to forcibly disarm any country that poses a gathering threat, and an unwillingness to be constrained by treaties or international institutions that don't suit us perfectly." 96 Rather than parroting Bush's line, pro-war liberals spelled out a distinctly liberal case for war with Iraq based on humanitarianism and antitotalitarianism, reflecting their optimistic-universal vision of liberalism.

Building on the rise of humanitarian interventionism in the 1990s, pro-war liberals argued that the Baathists' egregious crimes and tyrannical rule justified regime change. Iraq had become a "criminal state," in scholar Stanley Hoffmann's terms, whose aggression and human rights abuses abrogated its right to sovereignty. ${ }^{97}$ Although Saddam Hussein had committed his worst crimes in the late 1980s and early 1990s, he continued to kill, torture, and persecute thousands of Iraqis every year. ${ }^{98}$ Many liberals feared particularly for the Kurds,

\footnotetext{
${ }^{93}$ Cushman, "Introduction," 11.

${ }^{94}$ Tony Judt, “Bush's Useful Idiots.” See also Ryan, “Bush's 'Useful Idiots,” 670; Bérubé, The Left at War, 144.

${ }^{95}$ Stefan Halper and Jonathan Clarke, America Alone: The Neoconservatives and the Global Order (New York, 2004), 98-103.

${ }^{96}$ Bill Keller, “The I-Can't-Believe-I'm-a-Hawk Club,” New York Times, Feb. 8, 2003, A17. For similar claims, see Michael Ignatieff, “The American Empire: The Burden,” New York Times Magazine, Jan. 5, 2003, https://www. nytimes.com/2003/01/05/magazine/the-american-empire-the-burden.html (accessed Aug. 5, 2021); Al Gore, "Against a Doctrine of Pre-Emptive War," in The Iraq War Reader: History, Documents, Opinions, eds. Micah L. Sifry and Christopher Cerf (New York, 2003), 325-32, here 330-1; Christopher Hitchens, "Why I Am for Regime Change," in The Iraq War Reader: History, Documents, Opinions, eds. Micah L. Sifry and Christopher Cerf (New York, 2003), 440-4, here 442; and David Talbot, “All Conservative, All the Time," Salon, Feb. 28, 2003, https://www.salon.com/2003/02/28/alterman_3/ (accessed Aug. 5, 2021).

${ }^{97}$ Stanley Hoffmann, "Iraq and Just War: A Symposium," Pew Research Center, Sept. 30, 2002, https://www.pewforum.org/2002/09/30/iraq-and-just-war-a-symposium/ (accessed Aug. 5, 2021).

${ }^{98}$ For other liberals who evoked the humanitarian case for war, see Bob Kerrey, "Finish the War, Liberate Iraq," The Wall Street Journal, Sept. 12, 2002, A14; Jonathan Chait, "False Alarm: Why Liberals Should Support the War," The New Republic, Oct. 21, 2002, 18-21; David Remnick, "Making a Case," New Yorker, Feb. 3, 2003, 17; Salman Rushdie, "A Liberal Argument for Regime Change," Washington Post, Nov. 1, 2002, A35; Leon Wieseltier, "Against Innocence," The New Republic, Mar. 3, 2003, 26-8; and Thomas L. Friedman, "Tell the Truth," New York Times, Feb. 19, 2003, A25.
} 
who lived in an autonomous enclave in the north but who had been attacked on a genocidal scale in previous decades. ${ }^{99}$ Cushman put the humanitarian case as such: "Coming to the rescue and aid of a people who had been subjected to decades of brutality and crimes against humanity is entirely consistent with the basic liberal principle of solidarity with the oppressed and the fundamental humanitarian principle of rescue."

Pro-war liberals argued further that regime change might trigger democratization and other liberal reforms in the Middle East. ${ }^{101}$ While pro-war liberals did not guarantee that toppling Saddam Hussein would encourage democratization, they contended that strengthening democratic forces in the region would undermine many causes of extremism. As Packer contended, "Breaking the seal of tyranny in the Arab world and letting in fresh liberal air is a matter of our security as much as their freedom."

Many pro-war liberals further justified war with Iraq to prove the efficacy of multilateral institutions and international law, which formed key tenets of their overall foreign policy vision. Journalist Jonathan Chait argued that the best reason for war was enforcing the longstanding United Nations (UN) demand that Iraq destroy all its WMD programs. ${ }^{103}$ He wrote: "War with Iraq does not require trashing international law. Just the opposite: Sustaining international law is central to its very rationale.' ${ }^{, 104}$

It seems strange that these figures would back the war given Bush's failure to get UN authorization for the use of force. However, liberal support for formal UN approval for armed interventions had weakened during the 1990s in response to the international community's failures to address humanitarian crises. Pro-war liberals hoped that the United States would acquire clear UN Security Council authorization, but they considered this a bonus rather than a necessity given the UN's weaknesses. Ignatieff faulted Bush's "bullying tone" for the failure to get UN backing, but he asserted that previous resolutions from the 1990s justified the use of force to disarm Iraq. ${ }^{105}$ As he saw it, "The United Nations lay dozing like a dog before the fire, happy to ignore Saddam" before the United States compelled it to act. UN resolutions on human rights and disarmament were important, he admitted, "but they have no teeth unless America bares its fangs." ${ }^{\prime 06}$ For liberal hawks, enforcing international law against Iraq with "a law-bound community of nations," in Berman's phrasing, rather than the formal sanction of the sclerotic and divided United Nations could, in a roundabout way, revive that institution's legitimacy. ${ }^{107}$

Anti-totalitarianism formed another core motive for many liberal backers of the Iraq War. Since the Gulf War, pro-war liberals had conceived of Baathist Iraq as totalitarian, pointing to its absolute rule of Iraqi society and its roots in European fascism. Berman, for instance, argued that the Baath Party emerged in the 1940s from a mixture of communist, anti-Semitic, and

\footnotetext{
${ }^{99}$ Peter W. Galbraith, The End of Iraq: How American Incompetence Created a War Without End (New York, 2006), 1-15; Christopher Hitchens, “Appointment in Samarra?” Nation, Sept. 30, 2002, 9.

${ }^{100}$ Cushman, "Introduction," 2.

${ }^{101}$ George Packer, "The Liberal Quandary over Iraq," New York Times Magazine, Dec. 8, 2002, 104; Thomas Friedman, "Thinking About Iraq (I)," New York Times, Jan. 22, 2003, A21; Fareed Zakaria, "Invade Iraq, but Bring Friends," Newsweek, Aug. 5, 2002, 37; Tomasky, "Between Cheney and Chomsky," 45.

${ }^{102}$ Packer, "Introduction," 17.

${ }^{103}$ Chait, "False Alarm," 19; Jeffrey Goldberg, “Aflatoxin," Slate, Oct. 3, 2002, https://slate.com/news-and-politics/2002/10/aflatoxin.html (accessed Aug. 6, 2021). Liberal thought on Iraqi WMD is summarized in Deudney and Ikenberry, "Realism, Liberalism," 22.

${ }^{104}$ Chait, "False Alarm," 20. For similar claims, see Ignatieff, "American Empire;" Gore, "Against a Doctrine of Pre-Emptive War," 330-1; and Hitchens, "Why I Am for Regime Change," 442.

${ }^{105}$ Ignatieff, "Friends Disunited." See also Berman, "Friendly Drink," 57; and Friedman, "Tell the Truth," A25.

${ }^{106}$ Ignatieff, “American Empire.”

${ }^{107}$ Berman interview. For more on liberal hawks' thoughts on Bush's failure to get U.N. approval for the Iraq War, see Kate Zernike, "Some of Intellectual Left's Longtime Doves Taking on Role of Hawks," New York Times, Mar. 14, 2003, A16.
} 
fascist ideas transposed into Arab politics. The Baathists built totalitarian states in Syria and Iraq, ruling those lands with an iron fist, frequently attacking their neighbors, and preaching hatred against the West. Arab nationalists and Islamic extremists did not always get along, Berman conceded, but they concurred in "hatred of liberal civilization." ${ }^{108}$ Regime change in Iraq would not only preempt the possibility of Iraq and al-Qaeda working together but open the doors for political reform in the region. ${ }^{109}$

Exiles from Iraq and other Arab countries played a crucial role in shaping the liberal narrative of the Iraq War as an anti-totalitarian struggle. Ahmed Chalabi, the head of the Iraqi National Congress, claimed: "The Baathist ideology is rooted in the racist doctrines of 1930s fascism and Saddam has used the Baath to create a one-party totalitarian state." ${ }^{\prime 10}$ The influential Lebanese American political theorist Fouad Ajami likewise claimed that "the ideological roots" of Baathism "go back to National Socialism."111 Last, the scholar and activist Kanan Makiya had long framed Baathism as a successor of European fascism, especially in his widely read 1989 book, The Republic of Fear. ${ }^{112}$ He later likened Iraq to a "giant concentration camp where war would be liberating the prisoners," adding that the war "was primarily about overthrowing a morally outrageous regime." 113 Testifying to Makiya's influence, Packer wrote: "More than anyone else, Kanan Makiya guided my thinking."

The anti-totalitarian framing made the Iraq conflict into an ideological war in which the United States would create a beachhead of liberal democracy in order to counter totalitarianism in the Middle East. ${ }^{115}$ It also linked the Iraq War to the moral universalism of the New Vital Center; anti-totalitarianism was a political and ethical "vocation" for liberals, as Cushman described it, so they felt bound to oppose tyrants and back the oppressed everywhere. The fact that several prominent veterans of political campaigns against totalitarian states, including Vaclav Havel, Adam Michnik, and Jose Ramos-Horta, supported the war further bolstered the anti-totalitarian framing. ${ }^{116}$

Despite the significant contingent of pro-war liberals, numerous liberal intellectuals opposed invading Iraq. ${ }^{117}$ They included Power, Rieff, Tomasky, and New York Times journalist Nicholas Kristof, as well as prominent "refugees from the left" such as Walzer, Gitlin, and Kazin, who usually opposed U.S. military action and self-righteousness. Their opposition

\footnotetext{
${ }^{108}$ Berman, Terror and Liberalism, 42. For liberal writers who approached Iraq as totalitarian, see Beinart, "Fighting Faith," 22-3; Hoffmann, "Symposium: Drums of War, Calls for Peace," 11; Bill Keller, "The Selective Conscience," New York Times, Dec. 14, 2002, A29; and Remnick, "Making a Case," 17.

${ }^{109}$ Berman interview. See also Friedman, "Thinking About Iraq (I)," A21; and Hoffmann, "Symposium: Drums of War, Calls for Peace," 11.

${ }^{110}$ Ahmed Chalabi, "Iraq for the Iraqis," Wall Street Journal, Feb. 19, 2003, A14.

${ }^{111}$ U.S. Congress, Senate, Committee on Foreign Relations, Hearings to Examine Threats, Responses, and Regional Considerations Surrounding Iraq, 107 Cong., $2^{\text {nd }}$ sess., July 31, 2002, 129.

${ }^{112}$ Kanan Makiya, Republic of Fear: The Politics of Modern Iraq, 2nd ed. (Berkeley, CA, 1998), 130-42; Michelle Goldberg, "Radical Humanist, Iraq Hawk," Salon, Dec. 21, 2002, https://www.salon.com/2002/12/21/makiya/ (accessed Aug. 6, 2021).

${ }^{113}$ Kanan Makiya, interview by the author, Nov. 1, 2017.

${ }^{114}$ Packer, Assassins' Gate, 88. Hitchens, Goldberg, and Ignatieff also cited the influence of Makiya and other exiles. See Christopher Hitchens, "An Interview with Christopher Hitchens, Part II," in Hitchens and His Critics: Terror, Iraq, and the Left, eds. Simon Cottee and Thomas Cushman (New York, 2008), 201-18, here 202; Jeffrey Goldberg, "But It Is Genocide, Bob," Slate, Oct. 7, 2002, https://slate.com/news-and-politics/2002/ 10/but-it-is-genocide-bob.html (accessed Aug. 6, 2021); and Michael Ignatieff, "Getting Iraq Wrong," New York Times Magazine, Aug. 5, 2007, E26-9.

${ }^{115}$ Berman, Terror and Liberalism, 199.

${ }^{116}$ Rabinbach, "Totalitarianism Revisited," 82; Jose Ramos-Horta, “Sometimes, a War Saves People," in A Matter of Principle: Humanitarian Arguments for War in Iraq, ed. Thomas Cushman (Berkeley, CA, 2005), 281-4; Adam Michnik, "We the Traitors," Gazeta Wyborcza, Mar. 28, 2003, https://www.worldpress.org/article_model.cfm?article_id=1196\&dont=yes (accessed Aug. 6, 2021).

${ }^{117}$ For a summary of antiwar liberal thought, see Bérubé, Left at War, 122-4.
} 
derived from different interpretations of key liberal principles as well as more practical objections.

First, they disagreed with the idea that the Iraq War qualified as a legitimate humanitarian intervention. Walzer argued that this doctrine justified force only to stop massive crimes in progress or the imminent perpetration of crimes. Regime change could be a "consequence" of humanitarian intervention if the regime had committed enormous crimes and would likely do so again if left in power, but it could not be a primary reason for war. ${ }^{118}$ Walzer acknowledged that the Iraqi state inflicted reprehensible violence on its people, but this differed little from other authoritarian states such as North Korea. Its worst crimes occurred in the late 1980s against the Kurds, but humanitarian intervention did not justify the punishment of crimes long past. Walzer noted that the no-fly zones and the threat of U.S. retaliation had kept the Kurds relatively safe since the Gulf War. ${ }^{119} \mathrm{He}$ contended: "When genocide is going on, anybody who can stop it should stop it. But that's not the case in Iraq." went further by accusing Bush of using human rights as a "rationalization for a security operation," which she believed delegitimized the concept of humanitarian intervention. ${ }^{121}$

Antiwar liberals also further opposed the war on the grounds that containment could still manage the Iraqi threat. Walzer and others argued that the containment system of sanctions, inspections, and no-fly zones was both "proportionate to the threat" and effective in limiting Saddam's ability to produce WMD or threaten his neighbors. ${ }^{122}$ They backed renewed weapons inspections, which had destroyed the majority of Saddam's WMD in the 1990s. As Walzer argued, "Faced with a unified international community committed to the enforcement of inspections, with soldiers ready to move, Saddam would almost certainly suspend his pursuit." $^{\prime 23}$

The opposition of many New Vital Center liberals to the Iraq War also derived from a deeper suspicion of the optimism of both pro-war liberals and the Bush administration about liberal democracy in Iraq. Rieff, for example, claimed shortly after the invasion that Iraq, unlike Bosnia, lacked experience with democracy. This meant that the United States would have to build democratic norms and institutions from scratch in an economically ravaged country with a lack of common national identity. "I'm very skeptical of the ability of the United States to create democracies in places like Iraq, which have never had a democracy. These just seem to be utopian concepts," he concluded. ${ }^{124}$

Power likewise criticized Bush and the liberal hawks for not realizing how strong anti-Americanism had grown in the world and how this might upset plans to democratize Iraq. She lamented Americans' "amnesia," saying that while Americans focus on big-hearted, successful interventions like Bosnia or Kosovo, the world still recalls events like the bombing of Cambodia or CIA-backed coups in Guatemala, the Congo, and Chile. ${ }^{125}$ Kristof travelled in Iraq shortly before the war, and he noted that many Iraqis expressed hatred toward the

\footnotetext{
${ }^{118}$ Michael Walzer, "Iraq and Just War: A Symposium," Pew Research Center, Sept. 30, 2002, https://www.pewforum.org/2002/09/30/iraq-and-just-war-a-symposium/ (accessed Aug. 5, 2021); Michael Walzer, "Regime Change and Just War," Dissent 53, no. 3 (Summer 2006): 103-11; Samantha Power, The Education of an Idealist: A Memoir (New York, 2019), 137.

${ }^{119}$ Walzer, "Iraq and Just War"; Packer, Assassins' Gate, 82.

${ }^{120}$ Walzer quoted in "Liberal Debate on Iraq," Charlie Rose, prod. Yvette Vega, PBS, Dec. 13, 2002, https://charlierose.com/videos/24925 (accessed July 16, 2021); Michael Walzer, "No Strikes," The New Republic, Sept. 30, 2002, 19-22, here 21-2.

${ }^{121}$ Power, "Force Full."

${ }^{122}$ Walzer, "Iraq and Just War." See also Cohen, "Symposium: Drums of War, Calls for Peace," 13; and Galston, "Iraq and Just War."

${ }^{123}$ Walzer, "Iraq and Just War." See also Nicholas D. Kristof, “The Guns of September," New York Times, Sept. 13, 2002, A27.

${ }^{124}$ Rieff interview; Gary Hart, "A Detour from the War on Terrorism," Washington Post, Mar. 9, $2003, \mathrm{~B} 7$.

${ }^{125}$ Power, "Force Full”; Editorial, “Double Talk on Democracy,” New York Times, Oct. 6, 2002, C12.
} 
United States because of war and sanctions, warning that they would view U.S. occupation as colonialism. ${ }^{126}$ Antiwar liberals predicted that a U.S. invasion would lead to ethnic fragmentation, civil war, and regional chaos in spite of good intentions. ${ }^{127}$

In voicing these doubts, antiwar liberals straddled an ideological tightrope between moral universalism and a cautious-historical version of liberalism. On one hand, as liberals, they never rejected the idea that all human beings deserve rights and democracy. However, they expressed doubts about the moral credibility of the United States and its ability to achieve liberal ends in any given country at any given time-especially in Iraq. They anticipated the unintended consequences of U.S. actions and the fact that other societies did not share America's positive self-regard. While the optimistic-universal strand of liberalism dominated in the period immediately following $9 / 11$, the views of these skeptics reflected the continued relevance of the cautious-historical strand, which would rise to the forefront again after the failure of the Iraq War.

\section{Liberalism and the Arc of History since Iraq}

The rapid descent of the Iraq War into civil war and the failure to find weapons of mass destruction undermined the liberals' case for war and their broader post-9/11 project, causing numerous liberal hawks to express regret. Beinart admitted a feeling of "hubris" related to the successes of military interventions from the Gulf War to Kosovo and the spread of democracy in the 1990s. ${ }^{128}$ A chastened Packer concluded: “The Iraq War brought to an end the age of humanitarian intervention, which had helped to make it thinkable" and drew the lesson that "moral purpose combined with force, without knowledge and wisdom, can be more dangerous than indifference." 129 Others claimed that they would not have supported the invasion if they had known that Saddam did not have a serious unconventional weapons arsenal or that the Bush administration would botch the occupation. ${ }^{130}$

Since the early 2000s, U.S. liberals, as well as the Democratic Party, have retreated into a more defensive, inward-facing ideological posture, in part because of the Iraq War's failure. Barack Obama defeated Hillary Clinton in the 2008 primaries in large part because he had opposed the war, whereas Clinton had supported it. ${ }^{131}$ The near success of Senator Bernie Sanders in the 2016 and 2020 primaries reflected, in part, a rejection of the interventionist liberalism of the New Vital Center, given Sanders's longstanding opposition to U.S. wars since Vietnam. ${ }^{132}$ Polling data, moreover, suggests important shifts within the party of liberalism

\footnotetext{
${ }^{126}$ Nicholas D. Kristof, “The Stones of Baghdad,” New York Times, Oct. 4, 2002, A27; Fawaz A. Gerges, "Illusions of Iraqi Democracy," Washington Post, Oct. 8, 2002, A25.

${ }^{127}$ Galston, "Iraq and Just War"; Walzer, "Politics of Rescue," 57-60; Nicholas Kristof, "The Day After," New York Times, Sept. 24, 2002, A27; Cohen, "Symposium: Drums of War, Calls for Peace," 7-11.

${ }^{128}$ Eric Benson, "Liberal Hubris," New York Magazine, May 30, 2014, http://nymag.com/news/frank-rich/peterbeinart-iraq-war-2014-6/ (accessed Aug. 6, 2021). See also Richard Cohen, "How Did I Get Iraq Wrong?" Slate, Mar. 18, 2008, https://slate.com/news-and-politics/2008/03/i-was-miserably-wrong-in-my-judgment-and-somewhat-emotional.html (accessed Aug. 6, 2021); and Tom Keller, "My Unfinished 9/11 Business: A Hard Look at Why I Wanted War,” New York Times Magazine, Sept. 11, 2011, 124.

${ }^{129}$ Packer, Assassins' Gate, 460. See also George Packer, “The Trouble with Liberal Hawks," Slate, Jan. 12, 2004, https://slate.com/news-and-politics/2004/01/liberal-hawks-reconsider-the-iraq-war-the-trouble-with-liberal-hawks-1.html (accessed Aug. 6, 2021).

${ }^{130}$ Jonathan Chait, “Iraq: What I Got Wrong, and What I Still Believe," New York Magazine, Mar. 19, 2013, http://nymag.com/intelligencer/2013/03/iraq-what-i-got-wrong-and-what-i-still-believe.html (accessed Aug. 6, 2021); Jeffrey Goldberg, “How Did I Get Iraq Wrong?” Slate, Mar. 18, 2008, https://slate.com/news-and-politics/2008/03/ididn-t-realize-how-incompetent-the-bush-administration-could-be.html (accessed Aug. 6, 2021); Packer, Assassins' Gate, 461-2.

${ }^{131}$ David Remnick, The Bridge: The Life and Rise of Barack Obama (New York, 2010), 344-8.

${ }^{132}$ Uri Friedman, "The Sanders Doctrine," The Atlantic, Feb. 11, 2020, https://www.theatlantic.com/politics/ archive/2020/02/bernie-sanders-doctrine-america-military-foreign-policy/606364/ (accessed Aug. 6, 2021).
} 
on foreign intervention. Democrats opposed the idea of airstrikes against the Assad regime in Syria for its use of chemical weapons against civilians by a margin of 48 percent against to 29 percent in favor. ${ }^{133}$ Fifty-one percent of Democrats supported Obama's 2011 airstrikes against the Gaddafi regime in Libya, a case of humanitarian intervention, but this was fewer than the 57 percent of Republicans who backed the strikes. ${ }^{134}$ As of 2018, only 39 percent of Democrats listed defending human rights as a high foreign policy priority, and only 22 percent identified promoting democracy as such. ${ }^{135}$

Obama's foreign policy fit the trend of liberal retrenchment since the early 2000s. He said while campaigning in 2008 that he identified with the "foreign policy realism" of George H. W. Bush and his National Security Advisor, Brent Scowcroft. His administration featured several prominent humanitarian interventionists, especially Power and Susan Rice, who lobbied for U.S. military action in Syria and Libya. ${ }^{136}$ However, Obama hesitated to back antiauthoritarian protests in places such as Iran, Egypt, and Syria, fearing the consequences of destabilizing Middle Eastern societies. He did intervene to stop imminent atrocities in Libya and to roll back the Islamic State, but he intended to stop catastrophic events more than positively transform troubled parts of the world. ${ }^{137}$ While Obama deployed universalistic rhetoric about rights and democracy, his foreign policy implicitly recognized the growing limits of U.S. power and the pitfalls of democratic crusading. ${ }^{138}$

Nothing has been more destructive to optimistic-universal liberalism than the resurgence of right-wing, nativist authoritarianism in both new and well-established democracies in the 2010s. The nongovernmental organization Freedom House declared that 2019 marked the fourteenth consecutive year of "decline in global freedom," including the United States as a declining democracy in areas like government functionality, rule of law, and fair elections. ${ }^{139}$ Meanwhile, President Donald Trump, the avatar of these trends in the United States, rejected every aspect of the New Vital Center liberalism: he mocked alliances and global institutions, praised dictators, maligned immigration and cosmopolitanism, offered little support to democracy or human rights worldwide, and stymied progressive reforms at home. ${ }^{140}$ On a deeper level, he represented the type of nationalism the New Vital Center liberals most opposed, one based in a return to an imaginary glorious past and a view of the nation as defined by

133“Public Opinion Runs Against Syrian Airstrikes," Pew Research Center, Sept. 3, 2013, https://www.pewresearch.org/politics/2013/09/03/public-opinion-runs-against-syrian-airstrikes/ (accessed Aug. 6, 2021). Similar data are in "Opposition to Syrian Airstrikes Surges," Pew Research Center, Sept. 9, 2013, https://www.pewresearch.org/politics/2013/09/09/opposition-to-syrian-airstrikes-surges/ (accessed Aug. 6, 2021).

${ }^{134}$ Jeffrey M. Jones, “Americans Approve of Military Action Against Libya, 47\% to 37\%," Gallup, Mar. 22, 2011, https://news.gallup.com/poll/146738/americans-approve-military-action-against-libya.aspx (accessed Aug. 6, 2021).

135“Conflicting Partisan Priorities for U.S. Foreign Policy," Pew Research Center, Nov. 29, 2018, https://www. pewresearch.org/politics/2018/11/29/conflicting-partisan-priorities-for-u-s-foreign-policy/ (accessed, Aug. 6, 2021). See also "Views of Foreign Policy," Pew Research Center, Dec. 17, 2019, https://www.pewresearch.org/politics/2019/ 12/17/6-views-of-foreign-policy/ (accessed July 16, 2021).

${ }^{136}$ Rice served as U.S. ambassador to the United Nations from 2009-2013 and then National Security Advisor from 2013-2017. Power succeeded Rice at the United Nations, where she served from 2013-2017.

${ }^{137}$ James Mann, The Obamians: The Struggle Inside the White House to Redefine American Power (New York, 2012), 165-8, 285-6, 260-4, 278-9, 290-1.

${ }^{138}$ Obama's Cairo speech provides a good example of universalistic rhetoric. Barack Obama, "The President's Speech in Cairo: A New Beginning," Whitehouse.gov, June 4, 2009, https://obamawhitehouse.archives.gov/issues/ foreign-policy/presidents-speech-cairo-a-new-beginning (accessed Aug. 6, 2021). See also Mann, Obamians, 340-5.

${ }^{139}$ Sarah Repucci, "Freedom in the World 2020: A Leaderless Struggle for Democracy," Freedom House, Mar. 2020, https://freedomhouse.org/report/freedom-world/2020/leaderless-struggle-democracy (accessed Aug. 6, 2021). The Economist magazine also downgraded the United States to a "flawed democracy" status in 2019 and 2020. "Global Democracy Has Another Bad Year," The Economist, Jan. 22, 2020, https://www.economist.com/ graphic-detail/2020/01/22/global-democracy-has-another-bad-year (accessed Aug. 6, 2021).

${ }^{140}$ Steven Levitsky and Daniel Ziblatt, How Democracies Die (New York, 2018), 60-7. 
ancestry, race, and religion rather than shared ideals. ${ }^{141}$ In 2018, for instance, Trump denounced globalists and declared "I'm a nationalist okay? ... Use that word!"

All of these trends have intensified liberal commitment to a cautious-historical interpretation of their ideas. The fact that The Atlantic magazine had a special issue in 2019 entitled "How to Stop a Civil War" exemplifies the retreat of liberal ambitions. Liberal intellectuals have backtracked from post-Cold War dreams of global democratization to trying to save their own democracy from polarization, collapsing trust in institutions, and creeping authoritarianism. Historian Jill Lepore's recent defense of liberal nationalism, for instance, focuses on the eternal task countering of "illiberal, or ethnic nationalism" on the right and argues that the best way to promote liberal values abroad is by ensuring their vitality at home. ${ }^{143}$

The political theorist Corey Robin suggests that liberal support for the Iraq War and the War on Terror reflected the enduring grip of Shklar's liberalism of fear on the modern liberal imagination. With reformist hopes frustrated at home, he wrote, "fear offered a posture of militant, crusading purpose, an opportunity to impose the Enlightenment abroad precisely because it could not be defended at home." ${ }^{144}$ Yet in the years following 9/11, belief in the universality and transformative power of liberal ideas shaped liberal international thought as much as fear of terrorism or totalitarianism. Liberals also showed increasing confidence in the ability of U.S. power to achieve good in the world by championing democracy, defeating terrorists and rogue states, and intervening to stop atrocities. In short, optimism can drive liberal overreach as much as fear.

Historians can conclude that the interpretation of liberal principles in different contexts pivots in large part on liberals' sense of the momentum of history. In the 1990s, liberals had reason to believe that the arc of history pointed in their direction: successful humanitarian interventions, victory in the Cold War, and the global advance of democracy. By the mid-2010s, the trend lines pointed in the opposite direction, prompting the optimistic-universal mode of liberalism to wane. The New Vital Center thus appears as the apogee of post-Cold War liberal optimism about the direction of history, the universality of liberal ideals, and the potential of U.S. power to spread those ideals, all hardened by the clarifying urgency of the post-9/11 moment.

Joseph Stieb is a historian of U.S. political and diplomatic history. He is currently a postdoctoral research fellow at the Mershon Center for International Security Studies at the Ohio State University, Ohio, USA. He received his Ph.D. in U.S. history at the University of North Carolina at Chapel Hill in 2019. His first book is The Regime Change Consensus: Iraq in American Politics, 1990-2003 (Cambridge University Press, 2021). He has published additional work in The International History Review, The Washington Post, War on the Rocks, and Arc Digital.

\footnotetext{
${ }^{141}$ John B. Judis, The Nationalist Revival: Trade, Immigration, and the Revolt against Globalization (New York, 2018); Timothy Snyder, The Road to Unfreedom: Russia, Europe, America (New York, 2018).

${ }^{142}$ Quint Forgey, “Trump: 'I'm a Nationalist,"” Politico, Oct. 22, 2018, https://www.politico.com/story/2018/10/ 22/trump-nationalist-926745 (accessed Aug. 6, 2021).

${ }^{143}$ Jill Lepore, This America: The Case for the Nation (New York, 2019), 135-40; Jill Lepore, These Truths: A History of the United States (New York, 2018), xvii. For similar contemporaneous conceptions of the U.S. national project that reflect the return to a cautious-historical mode of liberalism, see Danielle Allen, Our Declaration: A Reading of the Declaration of Independence in Defense of Equality (New York, 2014); Jon Meacham, The Soul of America: The Battle for Our Better Angels (New York, 2018); and Anne Applebaum, Twilight of Democracy: The Seductive Lure of Authoritarianism (New York, 2020).

${ }^{144}$ Corey Robin, "Liberalism at Bay, Conservatism at Play: Fear in the Contemporary Imagination," Social Research 71, no. 4 (Winter 2004): 927-62, here 952. See also Corey Robin, "The Fear of the Liberals," Nation, Sept. 26, 2005, 13-8.
} 